\title{
Ethics of Regional Leadership with Local Wisdom of Siri 'Na Pacce in Makassar Ethnic Society
}

\author{
Muhammad Nur Yamin ${ }^{1}$, Novita Sari ${ }^{2}$ \\ Program Studi Ilmu Administrasi Negara, Universitas Negeri Makassar \\ E-mail: Nuryamin1@gmail.com ${ }^{1}, \underline{\text { novhyitashari789@ yahoo.co.id }}^{2}$
}

\begin{abstract}
The study aims to determine the application of regional leadership ethics with local wisdom of Siri na Pacce Makassar ethnic community seen from the values contained in it, namely Appau Tojeng, Lambusu', Jarrek, Sipakatau, Annyomba ri Karaeng La taala, and pacce. Continuity in the application of leadership values is reflected in the nature of leadership in the District Gowa Regency. The research method is descriptive qualitative, and the focus of research is on the leadership of the Regent of the Gowa Regency. Data collection techniques through interviews, observations, and documentation. Data on the research results were processed with the analysis technique model Miles and Huberman (2014). The results of the study show that local leadership ethics are still applied to a number of values, namely Appau Tojeng is applied through the union of words and actions taken; Jarrek is implemented through accountability for achieving the organization's vision and mission; Lambusu' is applied through open information delivery; Sipakatau is implemented through the provision of benefits, Annyomba ri Karaeng Allah Taala is implemented through religious activities carried out within the scope of his administration; and pacce is applied through caring for employees and the community. Evidence of the importance of applying the ethical values of local cultural heritage to the organization's leadership, so that leaders, employees, and communities can create a good governance atmosphere
\end{abstract}

Keywords: Ethics leadership; local wisdom; good governance

\section{INTRODUCTION}

Globalization is the interconnectedness and dependence between nations and between people. The process of transformation of the global order is progressing very rapidly, along with the progress of human civilization that gave birth to a lifestyle. Globalization is essentially a process of ideas that are raised, then offered and followed by other nations, which finally arrive at a point of mutual agreement and guide other nations throughout the world. The rapid flow of change does affect not only the community but also the organization's leaders who determine the success of an organization in achieving its goals.

Leaders, as the core of management activities, take an important task in determining the success of an organization. Activities affect other people, so they can work well together to achieve organizational goals. The success of a leader is greatly influenced by his leadership, which includes the ability to lead and interact with fellow leaders, subordinates, superiors, and capable of organizational leadership.

Leaders will show the ways of leadership in certain situations through words, attitudes, and behavior that can be felt directly by yourself or others who are strongly influenced by the leader's morals and ethics. Relationship Ethics leaders have a role in determining what is good and what is terribly done by someone. Hope as a leader who has a lot of power and control compared to the community or his subordinates so that they are required and required to have 


\section{Jurnal Administrare: Jurnal Pemikiran Ilmiah dan Pendidikan Administrasi Perkantoran Volume 7 Number 1, January-June 2020. Pages 173-180}

ethical responsibilities in accordance with the values and philosophies held by the Makassar tribal community.

Based on the background of the problem, the purpose of this research is to find out the application of ethics of the local wisdom siri 'na pacce of the Makassar ethnic community in regional leadership in Gowa Regency.

\section{METHOD}

\section{Approach and Type of Research}

This research is descriptive in nature with a qualitative analysis method aimed at assessing the extent to which the variables studied have been under established benchmarks. The location of the study was conducted at the Regional Secretariat Office (Sekda) of Gowa Regency.

\section{Description of Research Focus}

1. Appau tojeng. The behavior of a leader so that his followers can trust him-a leader who unites what he promises with what he does. Reliable leaders are able to reconcile the hearts of their followers so that they are more motivated to create uniformity for the sake of wholeness. The form of value is to say correctly and unite what was promised with what was done.

2. Lambusu'. The behavior of a leader is honesty. Being honest does not only tell the truth, but it also has to do with being open to others and revealing information to followers. The form of value is to be open and convey information to followers.

3. Jarrek. The attitude of the leader holds fast to the principles of belief and conviction-a leader who is consistent with what he says. The leader is responsible for all decisions made following the goals, vision, and mission of the organization. Leaders who apply the value of determination make it a role model for acting with certainty. The form of value is responsible for achieving the vision and mission and protect its followers.

4. Sipakatau. Human mutual understanding and respectful behavior. The leader creates harmony in his environment and allows all organizational and social activities to proceed appropriately according to the nature of human dignity. All social degrees are diluted; there is no difference between rich and poor, aristocratic, and ordinary people. The form of the value reflects the understanding, respecting, and equalizing perception through the shared vision and mission of the organization.

5. Annyomba Ri Karaeng Allah Taala. Behavior refers to self-control; leaders can use power wisely. Leaders use power based on faith and piety to God Almighty. The form of value is Taqwa behavior and faith in God Almighty.

6. Pacce. Leaders have more responsibility to care for the community or followers because of the more power they have. Pacce approach is a form of solidarity between the people of Makassar. Form of values, namely solidarity, and concern with the community and followers

\section{Research Informant}

The technique of withdrawing research informants was conducted purposively, research informants based on considerations were judged to have quality and accuracy to act as research 
subjects under the demands of the characteristics of the research problem. The informant is an Echelon II official at the Gowa Regency Regional Secretariat Office.

\section{Data Sources}

This study uses primary data sources from interviews directly with related parties to provide the necessary information with interview and observation techniques. Interviews were carried out using interview guidelines with question topics relating to research material. The observation was carried out to collect data in observing conditions related to the object of research. Secondary data sources were obtained from literature, documents, and historical texts that are relevant to the research material — data obtained through the study of documentation in the library or related agencies. Study documentation can take the form of writings, drawings, newspapers, magazines, inscriptions, or monumental works of a person. Data is collected from different informant sources; in this connection so that the triangulation of sources is not used so that data collection can be valid.

\section{Data analysis technique}

Data were analyzed using theme analysis from Miles, Huberman, and Saldana in Sugiyono (2014: 246), analyzing data in three steps: data reduction), data presentation, and drawing conclusions and verification.

\section{RESULTS AND DISCUSSION}

Discussion of research on the application of local wisdom Siri 'na Pacce of the Makassar ethnic community in leadership ethics at the Gowa Regency Regional Secretariat office. Leadership is the process of activities influencing people to follow the process of activities in the organization, in order to achieve predetermined goals. Influencing others means taking actions, including giving orders and carrying out other organizational management activities. To see the main points in this study can be seen from the value of appau tojeng, lambusu', jarrek, sipakatau, annyomba ri karaeng Allah Taala, and Pacce.

\section{Appau tojeng}

As we know that appau tojeng or telling the truth is a value contained in the philosophy of siri na pacce. Leaders who apply the value of appau tojeng are leaders who can be trusted because they unite what has been said with their actions.

Based on the concept from Wirawan (2014: 105) with the results of the study, it was found that there was a compatibility between the concept and the conditions on the ground, this is because the Regent of Gowa had made a political promise which up to now was implemented as his vision and mission. As for the words spoken by the Regent of Gowa, who adapted words to the environment, heeded his words and made himself an example to his employees, giving rise to appreciation or trust from his employees.

\section{Lambusu'}

Lambusu' is the value of honesty is the attitude of a leader who does not lie or deviate from the truth. The leader must be honest with himself, his followers, and people related to his 


\section{Jurnal Administrare: Jurnal Pemikiran Ilmiah dan Pendidikan Administrasi Perkantoran Volume 7 Number 1, January-June 2020. Pages 173-180}

organization. In other words, leaders can't lie. Honest leadership is also related to the nature of openness in conveying information, giving rise to the trust of employees.

Based on the concept from Wirawan (2014: 106) with the results of the study, it was found that the suitability of the concept with the conditions on the ground, this is because the Gowa Regent who always conveyed his information openly at each meeting, as well as utilizing social media such as the Gowa Regency Public Relations website (Gowakab.go id and humas.gowakab.go.id), Instagram and WhatsApp Groups to convey information. The Gowa Regent also conducts a survey to look at the needs of the community before formulating development policies, which makes the Gowa Regent trustworthy by the people and their employees.

\section{Jarrek}

Jarrek or persistence is a consistent value and sense of responsibility of a leader towards his task and role in the organization to achieve the organization's vision, mission, and goals. The leader must be responsible, protect, and develop his followers. Leaders who are able to apply the value of determination will make it a role model and are more valued by followers for acting consistently.

Based on the concept of Wirawan (2014: 106) with the results of the study, it was found that the suitability of the concept with the conditions on the ground, this is because the Regent of Gowa is responsible for the achievement of the vision, mission, and goals in the organization by paying attention to the course of the vision and mission that became the Strategic Plan and then down to Renja which was then divided into SKPD into RKA, can be seen from the 67 awards achieved during the three years of the Gowa Regent's administration, one of which ranked 21 se-Indonesia for the administration of local government was quoted in TribunNews.com. Although there are many obstacles encountered, it is a motivation to continue to run its vision and mission in order to achieve organizational goals. In addition, the leader of Gowa Regency is able to put himself in making new rules, first making these rules for himself so that they can be an example for his employees. This proves that the regent still applies Jarrek values by protecting his employees.

\section{Sipakatau}

The sipakatau value in the philosophy of siri na pacce is a value that requires the leader to treat his subordinates as well as he would like to be treated by his subordinates and others. He must understand and appreciate that everyone has differences in gender, age, cultural differences, educational differences, and experience. The leader must also respect the rights of others and those who are related to his organization. Leaders equate their perceptions and behaviors through a common vision, mission, goals, and organizational culture that must be obeyed by their followers as a consequence of being a member of the organization.

Based on the concept of Wirawan (2014: 105) with the results of the study, it was found that the suitability of the concept with the conditions in the field, this is because the Gowa Regent respects his employees through the provision of additional income allowances and rewards for employees who excel and can innovate, in addition to providing sanctions to institutions or SKPD that cannot run the program. In order to make the perception of the vision, mission, and goals of the organization similar to the values of the organization, even though in delivering input or opinions to the Regent of Gowa it must be protocular and tiered. However, in receiving 
input or opinions and suggestions from employee considering and adjusting to the vision and mission that has been made

\section{Annyomba ri karaeng Allah Taala}

As a leader who has power must be able to use his power wisely in influencing his subordinates and others related to his organization or government. In using this power, the leader must be based on the Annyomba ri karaeng Allah Taala value which states that a leader must be pious and have faith in God Almighty, as a basis for thinking and efforts to purify his conscience.

Based on the concept from Ermaya (1997: 21), it was found that the suitability of the concept with the conditions in the field, namely the Gowa Regent, was based on the value of taqwa and Godhead by enhancing religion such as organizing the enlightenment of the heart which is held every Friday by inviting famous preachers and issuing famous lecturers. Circular containing prayers on time in the government environment.

\section{Pacce}

Pacce value is a feeling of sadness and pain that is felt by someone soaking in someone's heart because of seeing the suffering of others. The value of Pacce in siri na pacce encourages, in reality, the existence of an act of help to help, the demand for defense as one of the functions of the means of raising unity, solidarity, togetherness, loyalty, a sense of humanity, and motivation to try even in difficult circumstances.

Based on the concept from Erman (2016) with the results of the study, it was found that the suitability of the concept with the conditions in the field, namely the Gowa District Head, upholds the value of pacce as seen from the Regent's concern for sick employees by providing some assistance. Not only to the employees, but the regent is also responsive to the problems that occur in the community.

\section{CONCLUSION}

The regent of Gowa Regency still applies the local leadership ethics based on the values contained in siri 'na pacce, this is proven that: 1) the Appau tojeng indicator is still applied because the regent of Gowa unites what is said with his actions as seen from the promises made by the regents of Gowa who applied as a Vision and Mission in the period of leadership and as a basis for making policies, 2) the leaders of Gowa Regency still apply Lambusu 'indicators or honesty because the Gowa District Head conveyed information openly both directly and indirectly through the official website of the Gowa Regency public relations page and Other Social Media. 3) Jarrek indicator or determination is also still applied by the Regent of Gowa because the Regent of Gowa is responsible for achieving the vision, mission, and goals in the organization by observing the course of his vision and mission and placing himself first in making rules. 4) The Sipakatau or Indicator is also still being implemented by the Gowa Regent by respecting his employees through the provision of benefits for employees or SKPD who are able to run their programs and can innovate. 5) Indicator of Annyomba ri karaeng Allah Taala is also still applied by the Regent of Gowa based on an almighty god. Seen from religious activities that are often carried out within the scope of his administration. 6) Pacce indicator is still applied with the care given by the Regent of Gowa to his employees suffering from illness 
178 Jurnal Administrare: Jurnal Pemikiran Ilmiah dan Pendidikan Administrasi Perkantoran
Volume 7 Number 1 , January-June 2020. Pages 173-180

or affected communities and acting responsive to problems experienced by the community and activities undertaken in an effort to increase solidarity among employees.

\section{REFERENCES}

Aaker, D. A., \& Joachimsthaler, E. (2000). Brand Leadership: Building Asset in the Information Society. New York, NY: Free Press.

Abdussamad, J., \& Akib, H. (2015). Effect of transformational leadership and organizational culture on employee performance toward the department of education, youth and sports Gorontalo Province, Indonesia. A qualitative study. International Journal of Academic Research, 7(1), 386-390.

Asmalah, L., \& Rialmi, Z. (2019). The Effect of Leadership and Motivation on Employee Performance at PT. Prima Lestari in Tangerang. PINISI Discretion Review, 3(2), 119-124.

Awaru, O. T. (2015). Pengaruh Gaya Kepemimpinan Transaksional dan Transformasional Terhadap Kinerja Guru SMA di Kabupaten Sinjai. Jurnal Ad'ministrare, 2(1), 27-35.

Batista-Taran, L. C., Shuck, M. B., Gutierrez, C. C., \& Baralt, S. (2017). The Role of Leadership Style in Employee Engagement. The Role of Leadership Style in Employee. https://doi.org/10.1016/1048-9843(95)90035-7

Bhardwaj, A., Mishra, S., \& Jain, T. K. (2020). Analysis of strategic leadership for organizational transformation and employee engagement. Materials Today: Proceedings. https://doi.org/https://doi.org/10.1016/j.matpr.2020.04.774

Eka, P. D. (2020). The Effect of Leadership and Motivation on Organizational Commitment at PT. Indo Perkasa Indonesia in Tangerang. PINISI Discretion Review, 1(2), 73-80.

Gerlach, S., Hämmerle, M., \& Schuler, S. (2019). Patterns for Analysis of Human Resource Flexibility in Manufacturing. Procedia Manufacturing, 39, 947-955. https://doi.org/https://doi.org/10.1016/j.promfg.2020.01.394

Gunartin, G. (2020). Analysis of the Village Head's Leadership Style in Cidokom Gunung Sindur Village, Bogor District. Jurnal Ilmiah Ilmu Administrasi Publik, $10(1), 75-84$.

Handayani, R. (2020). The Effect of Leadership Style and Work Discipline on Employee Performance at PT Indonesia Nippon Seiki Cikande Serang. PINISI Discretion Review, 3(1), 53-60.

Jantz, R. C. (2017). Vision, innovation, and leadership in research libraries. Information Science

Research, $39(3)$ 234-241. https://doi.org/https://doi.org/10.1016/j.lisr.2017.07.006

Lobanova, L., \& Ozolina-Ozola, I. (2014). Comparative Evaluation of the Practical Areas of Human Resource Management in Lithuania and Latvia. Procedia - Social 
and Behavioral Sciences, $\quad 110, \quad 607-616$. https://doi.org/https://doi.org/10.1016/j.sbspro.2013.12.905

Nasila, J. W., \& Akib, H. (2014). Participative leadership of village head based local wisdom" H4" in district suwawa, bolango bone regency, gorontalo province Indonesia. Global Journal of Business, Economics and Management, 4(1).

Nicolau, C., \& Foris, T. (2018). Human Resources Crisis: Identifying Future Entrepreneur's Profile in Romania. Procedia - Social and Behavioral Sciences, 238, 572-581. https://doi.org/https://doi.org/10.1016/j.sbspro.2018.04.037

Niswaty, R., Juniati, F., Darwis, M., Salam, R., \& Arhas, S. H. (2019). The Effectiveness of Leadership Functions Implementation in The Makassar Departement of Manpower. JPBM (Jurnal Pendidikan Bisnis Dan Manajemen), $5(1), 1-10$.

Rajamemang, R., Kasnawi, T., Anshari, A., Kahar, F., \& Maidin, R. (2019). Determinant Factor of Transformational Leadership in the Age of Globalization. Jurnal Ad'ministrare, 6(1), 73-78.

Saggaf, M. S., Nasriyah, N., Salam, R., \& Wirawan, H. (2018). The Influence of Teacher's Pedagogic Competence on Learning Motivation of Student of Office Administration Expertise Package.

Saggaf, M. S., Wahyuddin, B. A., Akib, H., \& Nasrullah, M. (2019). The Role of Principal Leadership in Vocational Schools Panca Sakti Makassar. Jurnal Office, 4(2), 53-62.

Wader, N., Darwis, M., Salam, R., \& Baharuddin, A. (2020). Application of the Transformational Leadership Style at the BKKBN office in South Sulawesi Province. PINISI Discretion Review, 1(1), 7-12.

Wirawan, H., \& Tandiayuk, S. (2019). The Role of Charisma and Psychological Capital on Credibility among Start-up Entrepreneurs. Jurnal Ilmiah Ilmu Administrasi Publik, 8(2), 107-120. 
180 Jurnal Administrare: Jurnal Pemikiran Ilmiah dan Pendidikan Administrasi Perkantoran Volume 7 Number 1, January-June 2020. Pages 173-180 